\title{
THE FAMILY PUPINIDAE IN BHUTAN (GASTROPODA: CAENOGASTROPODA: CYCLOPHOROIDEA)
}

\author{
EDMund GitTenberger ${ }^{1 *}$, Pema LedA ${ }^{2}$, SHerub SHERUB ${ }^{3}$, CHOKI GyeLTSHEN ${ }^{2}$ \\ ${ }^{1}$ Naturalis Biodiversity Center, P.O. Box 9517, NL-2300 RA Leiden, The Netherlands \\ (e-mail: egittenberger@yahoo.com) \\ ${ }^{2}$ National Biodiversity Centre, Serbithang, Thimphu, Bhutan \\ (e-mail: pemled12@gmail.com; chokig@gmail.com) \\ ${ }^{3}$ Ugyen Wangchuck Institute for Conservation and Environmental Research, Bumthang, Bhutan \\ (e-mail: sherubird@gmail.com) \\ *corresponding author
}

ABSTRACT: Only three genera of Pupinidae are known now to be represented in Bhutan, viz. Pseudopomatias with at least two species, including P. barnai n. sp., and Streptaulus and Schistoloma, both with one species. The records for these species fill gaps in published distribution maps.

KEY WORDS: taxonomy, Pseudopomatias, Streptaulus, Schistoloma, distribution, Bhutan

\section{INTRODUCTION}

After many years of neglect, there is an ongoing project now, aiming at an inventory of the mollusc fauna of the Kingdom of Bhutan. The country is situated in the south-eastern border zone of the Himalaya, an area that is biogeographically particularly interesting since it is transitional between the Palaearctic region in the north and the Indo-Malayan region in the south. Most of the original literature on the mollusc fauna of the eastern Himalaya was published in the 19th and early 20th century and dealt with the territory of 'British India' that never included Bhutan. As a consequence, nearly all records for that country are new, often filling gaps in published distribution maps, where Bhutan was hitherto an empty area (GITTENBERGER et al. 2018). Two recent monographs about different genera of Pupinidae L. Pfeiffer, 1853, by PÁLL-GergelY et al. (2014, 2015) exemplify this fact, while facilitating the identification of the pupinid shells that were collected in Bhutan recently. The three genera that are known now from that country are dealt with in this article, viz. Pseudopomatias Möllendorff, 1885, with at least two species, one of which is new to science, and Streptaulus Benson, 1857, and Schistoloma Kobelt, 1902, with one species each. The taxonomical and distributional data for these taxa are summarised.

\section{MATERIAL AND METHODS}

Within the scope of the Bhutan Evertebrata Inventory Project that was started 2012 by (1) the National Biodiversity Centre in Serbithang, Thimphu, Bhutan, (2) the Ugyen Wangchuck Institute for Conservation and Environmental Research in Bumthang, Bhutan, (3) Naturalis Biodiversity Center, in Leiden, The Netherlands, and (4) associated in- stitutes, molluscs were collected at many places in Bhutan (GITTENBERGER et al. 2018). This resulted in a quickly growing reference collection in the National Biodiversity Centre in Serbithang, Thimphu, Bhutan, where the material that is mentioned in this article is housed. The shells were measured with an electric caliper and photographed by using a Canon EOS 7D 
camera with an ER25 extension tube and a SIGMA DC lens. The number of whorls was counted as in KERNEY \& CAMERON (1979: 13).

Abbreviations: a.s.l. - above sea level; B - shell breadth; H - shell height; NBCB - National
Biodiversity Centre, Serbithang, Thimphu, Bhutan; RMNH - Naturalis Biodiversity Center, Leiden, The Netherlands.

\section{SYSTEMATIC PART}

\section{Family Pupinidae L. Pfeiffer, 1853}

\section{Genus Pseudopomatias Möllendorff, 1885}

Type species: P. amoenus Möllendorff, 1885, by monotypy.

Remarks: Very few shells of Pseudopomatias were found, most of them in poor condition.

\section{Key to the species of Pseudopomatias from Bhutan}

1a. Shell base with 3-4 coarse tubercles: ....... 2 .

1b. Shell base with parallel radial ribs only: P. barnai n. sp.

2a. Spiral microsculpture very fine or hardly discernible: . . . . . . ................ 3.

2b. Spiral microsculpture prominent: Pseudopomatias sp. 1

3a. Body whorl regularly convex: Pseudopomatias sp. 2

3 b. Body whorl flattened below the shallow suture: $P$. prestoni Páll-Gergely, 2015

Pseudopomatias barnai Gittenberger et Leda n. sp.

Figs 1-3

Pseudopomatias spec. GITTENBERGER et al. (2017: 36, fig. 21).

Type series. Holotype (NBCB28) and paratype (NBCB29); district Tsirang, $35 \mathrm{~km} \mathrm{WNW} \mathrm{of}$
Gelephu, altitude $1,050 \mathrm{~m}$ a.s.l., $27^{\circ} 01^{\prime} \mathrm{N}, 90^{\circ} 08^{\prime} \mathrm{E}$; E. GitTENBERGER \& PEMA LEDA leg. 23-03-2016.

Diagnosis. Shell with regularly convex whorls, sculptured with equally sized parallel ribs, and a broad apertural lip.

Description. Shell slender conical, with $6 \frac{1}{2}$ (paratype) - 7 (holotype) moderately convex whorls that are separated by a deep suture. In basal view (Fig. 3) the umbilicus is nearly entirely covered by the columellar part of the apertural lip. Aperture little higher than broad; peristome with a strongly thickened and reflected outer ring and a protruding inner ring. The radial ribs are fading on the final quarter of the last whorl; elsewhere they are sharp and little narrower than the interspaces. The ribs are neither interrupted nor thickened on the base of the shell. There is an indistinct micro-sculpture of very fine spiral lines.

Measurements. Holotype, H $7.0 \mathrm{~mm}$, B $3.8 \mathrm{~mm}$; paratype (damaged), H $6.2 \mathrm{~mm}$, B unknown.

Differentiation. Since only two specimens could be studied, the variability of the conchological characters remains unclear. In size and shape and in the broadly thickened apertural lip, P. barnai n. sp. is most similar to P. himalayae (Benson, 1859) (Figs 4-5), which differs most clearly in shell sculpture. In $P$. barnai $\mathrm{n}$. $\mathrm{sp}$. all radial ribs continue on the base of the shell, without increasing in prominence (Fig. 3). In $P$. himalayae, on the final half of the shell, about $50 \%$ of the ribs end before reaching the shell base, whereas the ribs that continue towards the umbili-

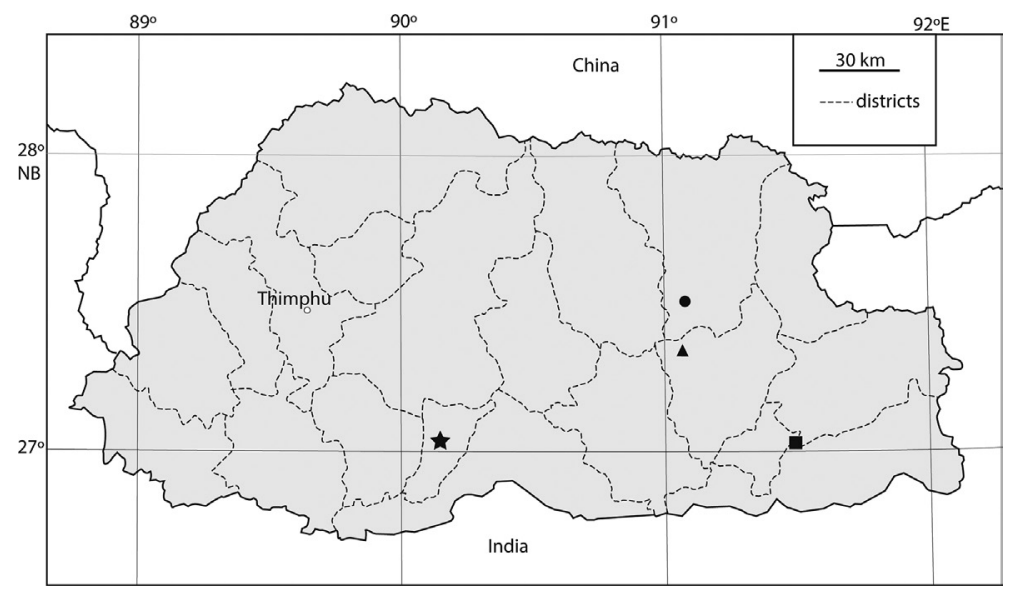

Fig. 1. Records of Pseudopomatias species: Pseudopomatias barnai n. sp., star; Pseudopomatias prestoni Páll-Gergely, 2015, dot; $P$. spec. 1, square; $P$. spec. 2, triangle 


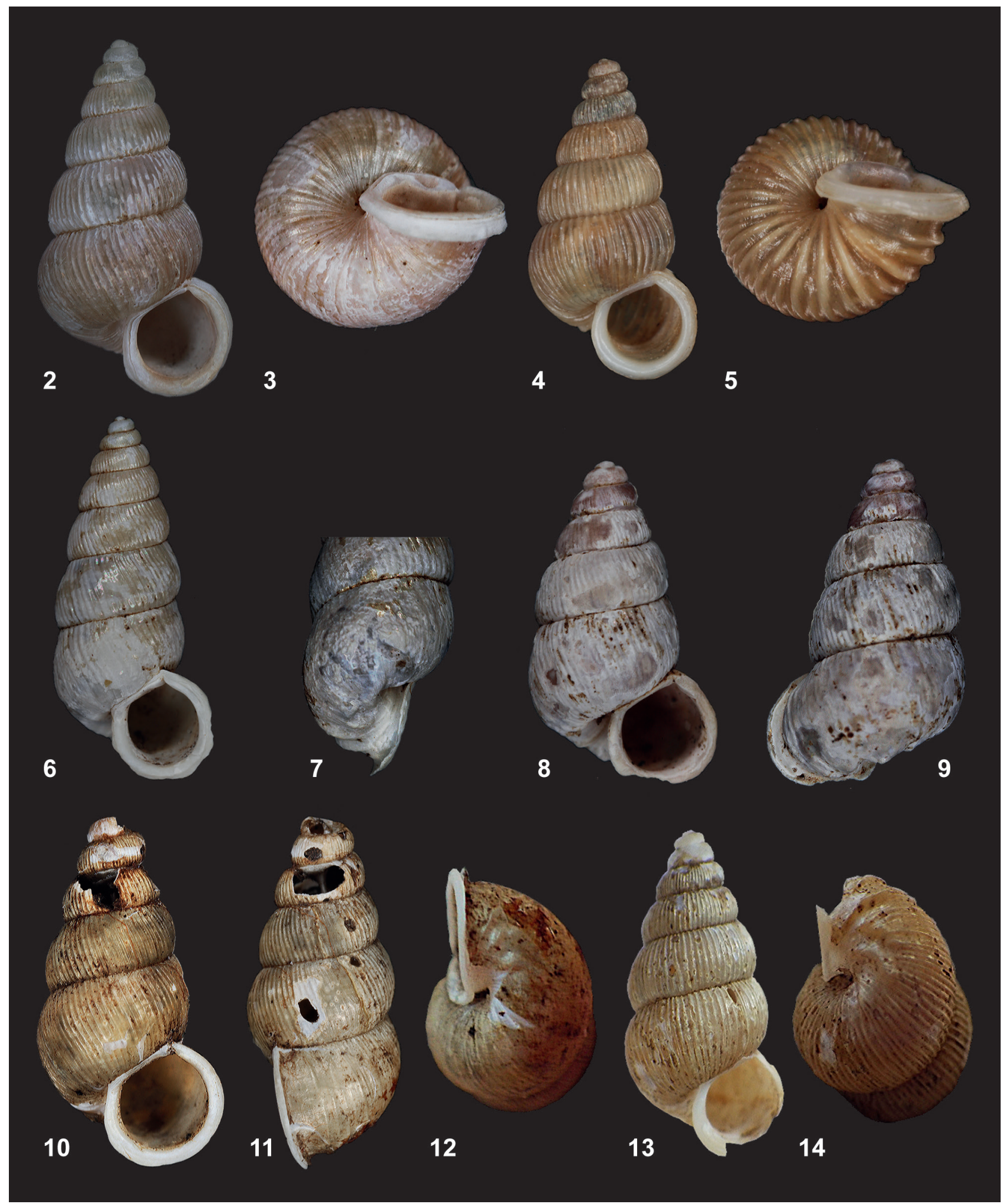

Figs 2-14. Pseudopomatias species: 2-3 - P. barnai n. sp., holotype (NBCB28), district Tsirang, $35 \mathrm{~km}$ WNW of Gelephu, altitude 1,050 m a.s.1.; frontal (2) and basal (3) view; shell height $7.0 \mathrm{~mm}$, width $3.8 \mathrm{~mm}$; 4-5 - Pseudopomatias himalayae (Benson, 1859) from the type locality, India, Sikkim, 'Darjeeling' (RMNH 156466); frontal (4) and basal (5) view; shell height $6.5 \mathrm{~mm}$, width $3.5 \mathrm{~mm}$; 6-9-P. prestoni Páll-Gergely, 2015 (NBCB30), district Lhuentse, Garbrag (Phag Sang), $11 \mathrm{~km} \mathrm{~W}$ of Gorgon, altitude 1,800 m a.s.l.; frontal $(6,8)$, oblique-basal (7) and oblique-lateral view (9); shell height $9.3 \mathrm{~mm}$ (6) and $5.7 \mathrm{~mm}$ (8), shell width $4.3 \mathrm{~mm}$ (6) and $3.2 \mathrm{~mm}$ (8); 10-12 - Pseudopomatias spec. 1, district Mongar, $16 \mathrm{~km}$ WNW of Mongar, altitude 2,625 m a.s.l.; frontal (10), lateral (11), and basal (12) view; shell height c. $8.0 \mathrm{~mm}$, width $3.5 \mathrm{~mm}$; 13-14 - Pseudopomatias spec. 2, district Pemagatshel, $7 \mathrm{~km}$ E of Pemagatshel, altitude 2,300 m a.s.l.; frontal (13) and oblique-basal (14) view; shell height $7.4 \mathrm{~mm}$ (13) 
cus are thickened (Fig. 5). The palatal-basal apertural lip is more regularly curved in $P$. himalayae, so that the aperture is more regularly circular in frontal view; the umbilicus seems to be slightly wider.

Etymology. Pseudopomatias barnai n. sp. is named after BARNA PÁLL-GERGELY, the first author of a recent revision of the genus Pseudopomatias.

\section{Pseudopomatias prestoni Páll-Gergely, 2015}

Figs 1, 6-9

Pseudopomatias prestoni PÁlL-GERGELY (2015: 27, fig. 10A-B) 'Damsang Peak, Sikkim, W. Bhutan' [India, West Bengal, near the border between Sikkim and West Bengal].

Material. District Lhuentse, Garbrag (Phag Sang), $11 \mathrm{~km}$ W of Gorgon, altitude 1,800 m a.s.1., 2730' N, 91 04'E; UGYEN TENZIN, DAWA YOEZER \& SHERUB SHERUB leg. 22-02-2017 (2 shells; NBCB30).

Description $(n=2)$. Two worn shells that are quite different in the number of whorls (6 and 73/4) and in size ( $\mathrm{H} 5.7$, B $3.2 \mathrm{~mm}$ and $\mathrm{H} \mathrm{9.3,} \mathrm{B} 4.3 \mathrm{~mm}$ ) agree well with the original description of $P$. prestoni. The lower whorls are separated by a rather shallow suture and are flattened above the periphery. The apertural lip is relatively thin and reflexed. The radial ribs are broader than the interspaces and at some rather well preserved parts there is a sculpture of hardly discernible, fine spiral lines. The final quarter of the body whorl is heavily worn, but 3-4 coarse tubercles on the shell base are clearly seen, decisively supporting this identification.

Distribution. This species was hitherto known from West Bengal and Sikkim in India only (PÁLL-GERGELY 2015: 27).

\section{Pseudopomatias sp. 1}

Figs 1, 10-12

Material. District Mongar, $16 \mathrm{~km} \mathrm{WNW} \mathrm{of}$ Mongar, altitude 2,625 $\mathrm{m}$ a.s.1., $27^{\circ} 19^{\prime} \mathrm{N}, 91^{\circ} 04^{\prime} \mathrm{E}$; E. GitTenBerger \& PEMA LEDA leg. 12-04-2015 (1 shell; NBCB 1072).

Notes. A single, damaged shell ( $\mathrm{H} 8.0$, B $3.8 \mathrm{~mm}$ ) cannot unreservedly be identified as $P$. prestoni, although it has 4 conspicuously coarse, allegedly diagnostic, irregular tubercles on the base (Fig. 12). It differs in a thick periostracum with a prominent spiral microsculpture. The blunt radial ribs become more widely spaced and are less prominent on the final quarter of the body whorl. The suture is deeper and the aperture is relatively larger than in $P$. prestoni from Lhuentse. The apertural lip is relatively thin and reflexed.

\section{Pseudopomatias sp. 2}

Figs 1, 13-14

Material. District Pemagatshel, $7 \mathrm{~km} \quad \mathrm{E}$ of Pemagatshel, altitude 2,300 m a.s.1., $27^{\circ} 01^{\prime} \mathrm{N}$, 9129'E; E. GiTTENBERGER \& PEMA LEDA leg. 14-042015 (2 shells; NBCB1073).

Notes. Only one fully grown shell (H $7.4 \mathrm{~mm}, \mathrm{~B}$ ?, $6 \frac{1}{2}$ whorls), with a part of the apertural wall missing (Fig. 13), and a juvenile, fresh shell with $5 \frac{1}{2} 2$ whorls, are available. As in Bhutanese $P$. prestoni and $P$. spec. 1 there are ca. 4 coarse, irregular tubercles on the base of the shell (Fig. 14). The radial ribs are sharp and as broad as the interspaces, and the suture is deeper than in $P$. prestoni. There is an indistinct, very fine spiral microsculpture.

\section{Genus Streptaulus Benson, 1857}

Type species: Streptaulus blanfordi Benson, 1857, by monotypy

\section{Streptaulus blanfordi Benson, 1857}

Figs 15-17

Streptaulus blanfordi BENSON (1857: 201), India, Sikkim, 'Darjiling', PÁlL-Gergely et al. (2014: 568, fig. 2), GITTENBERGER et al. (2017: 35, fig. 20).

Material. District Pemagatshel: N-side of Pemagatshel, altitude $1,750 \mathrm{~m}$ a.s.1., $27^{\circ} 02^{\prime} \mathrm{N}$, 9125'E, E. GitTenBerger \& PeMA LedA leg. 1504-2015 (1 shell; NBCB 1074); District Lhuentse: Garbrag (Phag Sang), $11 \mathrm{~km}$ W of Gorgon, altitude

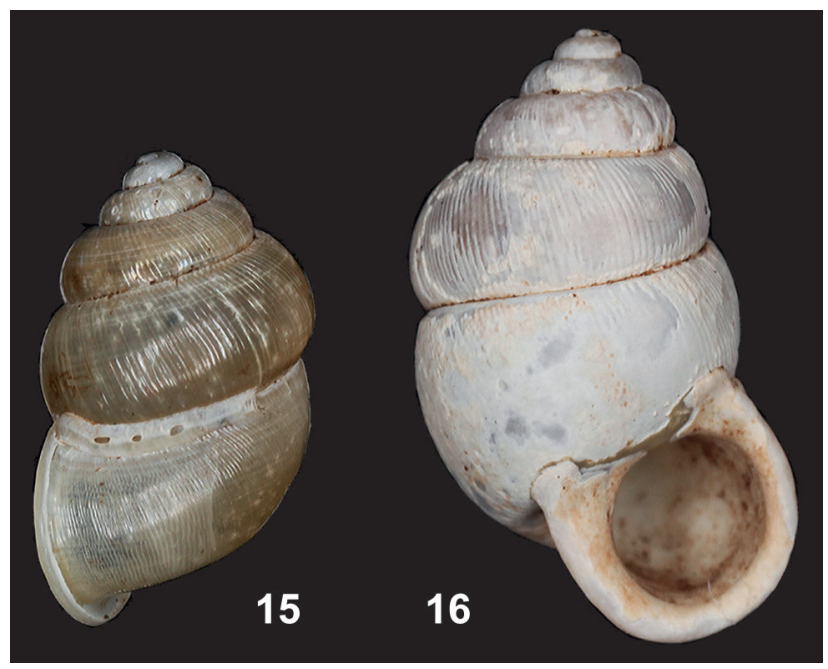

Figs 15-16. Streptaulus blanfordi Benson, 1857. District Lhuentse, Garbrag (Phag Sang), $11 \mathrm{~km} \mathrm{~W}$ of Gorgon, altitude 1,800 $\mathrm{m}$ a.s.1.; shell heights 6.6 and $8.3 \mathrm{~mm}$, respectively 


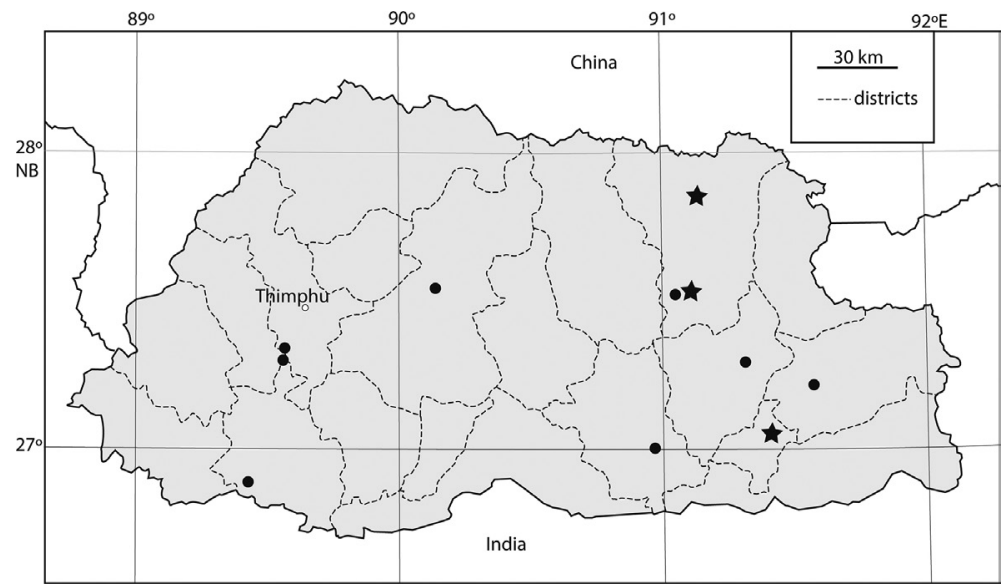

Fig. 17. Records of Streptaulus blanfordi Benson, 1857 (stars) and Schistoloma funiculalum (Benson, 1838) (dots)

1,800 $\mathrm{m}$ a.s.1., $27^{\circ} 30^{\prime} \mathrm{N}, 91^{\circ} 04^{\prime} \mathrm{E}$, UGYEN TENZIN, DAWA YOEZER \& SHERUB SHERUB leg. 22-02-2017 (2 shells; NBCB 1075); Dungkhar, $20 \mathrm{~km}$ NNW of Lhuentse, altitude 2,800 $\mathrm{m}$ a.s.1., $27^{\circ} 50^{\prime} \mathrm{N}, 91^{\circ} 07^{\prime} \mathrm{E}$, CHOKI Gyeltshen \& KEZANG TOBgAY leg. 23-052017 (1 shell; NBCB 1076).

Description $(n=4)$. Shell pale greyish, with 5-6 convex whorls, ovoid apart from the aperture, conspicuously glossy and covered with dense, radial riblets that become more narrowly spaced and finer near the aperture. Apertural lip whitish, broadly thickened and reflexed. With a broad sutural tube running backwards for $1 / 4$ whorl behind the lip.

Measurements. H 6.6-8.3 mm, B 4.1-5.0 mm, 5-6 whorls.

Distribution. According to GUDE (1921: 164), this species occurs in NE India, in Sikkim and Assam. In has not been reported for Nepal by BUDHA et al. (2015). The three records in Bhutan are in the eastern third of the country, at altitudes ranging from 1,750 to $2,800 \mathrm{~m}$ a.s.1.

Notes. The two shells from the district of Lhuentse, with 5 and 6 whorls, respectively, are quite different in measurements, i.e. $\mathrm{H} 6.6 \mathrm{~mm}, \mathrm{~B} 4.3 \mathrm{~mm}$ and $\mathrm{H}$ $8.3 \mathrm{~mm}$, B $5.0 \mathrm{~mm}$. A shell from the type locality is illustrated by PÁLL-GERGELY et al. (2014: 568, fig. 2); according to the scale bar it is larger than the shells from Bhutan, measuring ca. $11 \mathrm{~mm}$ in height. See PÁlL-GERGELY et al. (2014) for additional data.

\section{Genus Schistoloma Kobelt, 1902}

Type species: Cyclostoma altum Sowerby, 1842, by subsequent designation (GUDE 1921: 168).

\section{Schistoloma funiculalum (Benson, 1838)}

Figs 18-21

Cyclostoma funiculalum BENSON (in HUTTON \& BENSON 1838: 217), 'Indian Himalaya'.
Cyclostoma pauperculum SOWERBY [1] (1850: 166*, pl. 31B fig. 318), 'Bootan' (Bhutan before the AngloBhutan war of 1864).

Cyclostoma funiculatum SOWERBY [1] (1850: 166*, pl. 31B figs 316, 317), 'Khasya' [Khasi] Hills, India.

Schistoloma funiculalum - GITTENBERGER et al. (2017: 37).

Material. District Chhukha, secondary road Phuentsholing - Pasakha, shrubbery and rocks in a road curve, altitude $350 \mathrm{~m}$ a.s.1., $26^{\circ} 53^{\prime} \mathrm{N}, 89^{\circ} 25^{\prime} \mathrm{E}$, E. GitTENBERGER, PEMA LEDA \& LEKI DORJI leg. 09-042013 (2 shells; NBCB 1079); District Mongar, Kori La $12 \mathrm{~km}$ E of Mongar, altitude 1,969 m a.s.1., 27 $18^{\circ} \mathrm{N}$, 9119'E, KARMA WANGDI leg. 29-05-2017 (1 shell; NBCB 1080); District Paro, small gully with high rock-face at $\mathrm{N}$-side, altitude $2,150 \mathrm{~m}$ a.s.1., $27^{\circ} 18^{\prime} \mathrm{N}$, 89³3'E, E. GiTTENBERGER \& PEMA LEDA leg. 07-042013 (1 shell; NBCB 1081), District Thimphu, $16 \mathrm{~km}$ SSW of Thimphu, $3 \mathrm{~km} \mathrm{~N}$ of bridge, altitude 2,100 $\mathrm{m}$ a.s.1., $27^{\circ} 20^{\prime} \mathrm{N}, 8^{\circ} 34^{\prime} \mathrm{E}$, E. GITTENBERGER \& PEMA LEDA leg. 06-04-2013 (1 shell; NBCB 1082); District Trashigang, Khaling, 2,188 $\mathrm{m}$ a.s.1., $27^{\circ} 12^{\prime} \mathrm{N}, 91^{\circ} 34^{\prime} \mathrm{E}$, W. KLEIN leg. 02-06-2017; District Lhuentse, Garbrag (Phag Sang), $11 \mathrm{~km} \mathrm{~W}$ of Gorgon, altitude 1,800 m a.s.1., 2730'N, 91 04'E, UGYEN TENZIN, DAWA YOEZER \& SHERUB SHERUB leg. 22-02-2017 (1 shell; NBCB 1083); District Wangdue Phodrang, $5 \mathrm{~km}$ before Nobding from Wangdue Phodrang, $27^{\circ} 32^{\prime} \mathrm{N}$, 9008'E, SHERUB SHERUB leg. 30-04-2015 (shell fragments; NBCB 1078); District Zhemgang, Memalam Drimgang (Panbang), altitude 1,582 $\mathrm{m}$ a.s.l., under banana, $26^{\circ} 59^{\prime} \mathrm{N}, 90^{\circ} 58^{\prime} \mathrm{E}$, TSHETHUP TSHERING leg. 25-01-2016 (1 shell; NBCB 1077).

Description. Shell shiny, dark to yellowish chestnut-brown, slender spindle-shaped except for the flaring final half of the last whorl; with 7-71/4 slightly convex whorls. Teleoconch with dense, fine growth lines and alternating coarser ones; last whorl with a vague, irregularly knobby sculpturing, which may be somewhat spirally arranged below the periphery. Peristome continuous, circular, light yellowish 


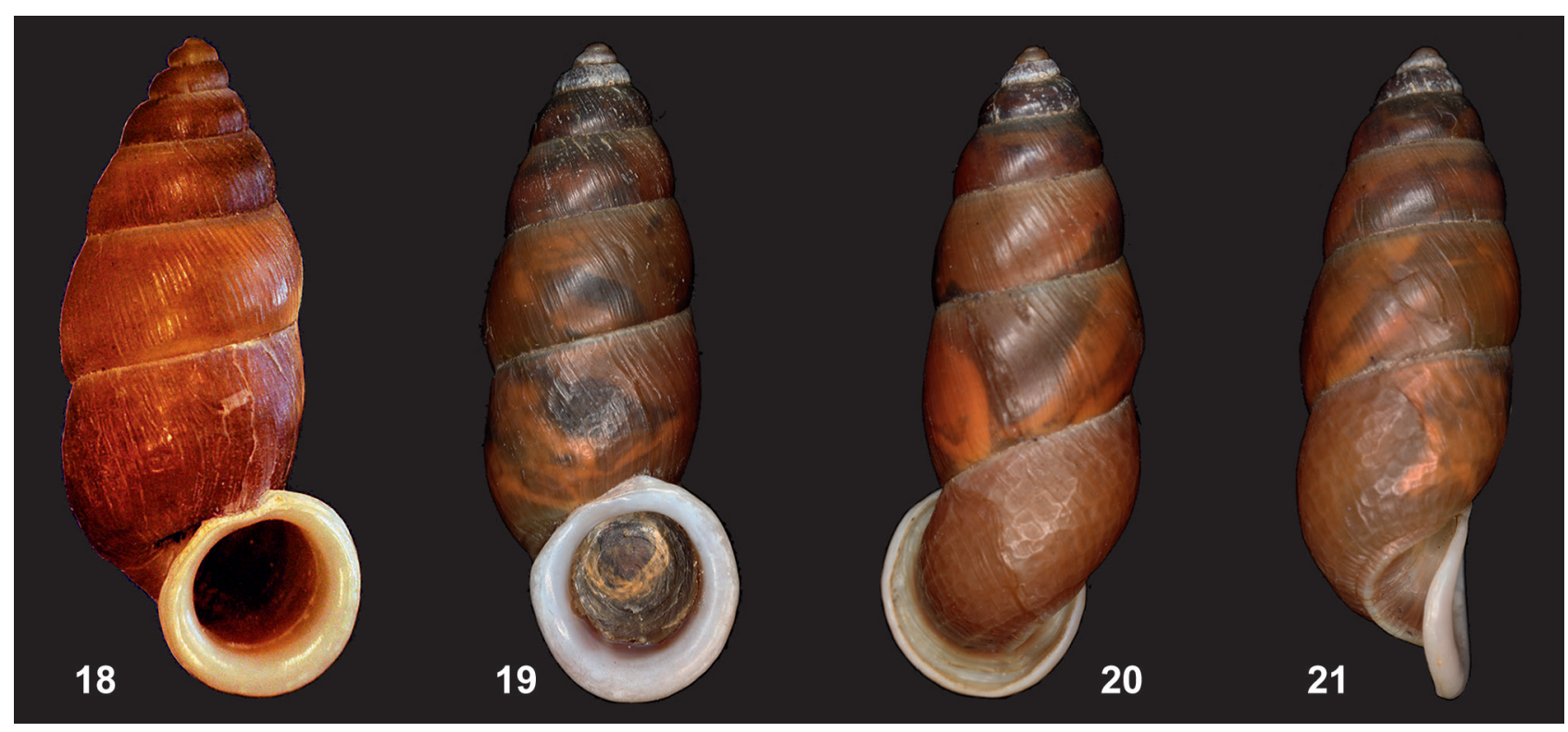

Figs 18-21. Schistoloma funiculalum (Benson, 1838): 18 - district Chhukha, along secondary road Phuentsholing-Pasakha, altitude 350 m a.s.l.; shell height $17.8 \mathrm{~mm}$; 19-21 - district Trashigang, Khaling, altitude 2,188 m a.s.l.; frontal (19), dorsal (20) and lateral-oblique view (21); shell height $25.2 \mathrm{~mm}$

brown to whitish, very strongly thickened and entirely reflexed. Umbilicus narrowly open and surrounded by a prominent, erect ridge, which may be whitish (Fig. 21) or not contrasting with the whorls in colour. Measurements. H 17.0-25.2 mm; B 7.3-10.3 mm. Distribution. Schistoloma funiculalum is known from Nepal (BUDHA et al. 2015: 8, 32) and the Khasi Hills in NE India. The new records for Bhutan are situated at altitudes ranging from 350 to $2,150 \mathrm{~m}$ a.s.l.

Notes. According to the original description and figure, Cyclostoma pauperculum Sowerby [1], 1850, is based on shells that are little smaller and less slender than S. funiculalum. Taking into account the variation that we observed in S. funiculalum, we consider C. pauperculum a junior synonym. Schistoloma tanycheilus (Godwin-Austen, 1876), referred to as S. tanychilum by GUDE (1921: 171), might be a second NE Indian Schistoloma species or subspecies, characterised by larger dimensions, a more prominent umbilical ridge and a more yellowish colour.

We consider tanycheilus a noun in apposition and do not accept the spelling tanychilum. As for the epithet funiculalum versus funiculatum we follow BUDHA et al. (2015: 32).

\section{DISCUSSION}

Malacology is still in its infancy in Bhutan, but we may already accept that the molluscan fauna of that country (GITTENBERGER et al. 2017) differs substantially, at least at the species level, from that of other parts of the southern Himalayan border zone, in particular Nepal, that is best known now (BUDHA et al. 2015). Judging the degree of mollusc endemism for Bhutan would be premature, also because of the incomplete data for the surrounding countries.

\section{ACKNOWLEDGEMENTS}

We are grateful to Messrs DawA YoEZer, KaRMA WANGDI, KEZANG TOBGAY, LEKI DORJI, NIMA GYELTSHEN, TSETHuP TSHERING, UgYeN TENZIN

and WIM KLEIN, who assisted in collecting molluscs and to Messrs ERIK-JAN BOSCH, who composed the distribution map and HENK CASPERS, who prepared the photographic illustrations. We also thank Ms. SANGAY DEMA, head of the Biodiversity Information Management Program of the National Biodiversity Centre, Dr. TASHI YANGzOME DORJI, Program Director, NBC, who both contributed in various ways to this project. We gratefully acknowledge the constructive remarks of three reviewers who enabled us to improve this article. This work has been supported by the Global Exploration Fund of the National Geographic Society (grant GEFNE 131-14) and the Bhutan Trust Fund for Environmental Conservation (grant MB0149Y15). 


\section{REFERENCES}

BENSON W. H. 1857. Characters of Streptaulus, a new genus, and of several species of the Cyclostomacea from Sikkim, the Khasia Hills, Ava, and Pegu. The Annals and Magazine of Natural History, including Zoology, Botany, and Geology 19: 201-211. Available online at https:// www.biodiversitylibrary.org/item/19414\#page/235/ mode/lup

Budha P. B., Naggs F., Backeljau T. 2015. Annotated checklist of the terrestrial gastropods of Nepal. ZooKeys 492: 1-48. https://doi.org/10.3897/zookeys.492.9175

GitTenberger E., LedA P., Gyeltshen C., SHERUB S., DEMA S. 2017. A field guide to the common molluscs of Bhutan. National Biodiversity Centre, Thimphu.

GitTenberger E., LedA P., Gyeltshen C., Sherub S. 2018. Distributional patterns of molluscan taxa in Bhutan (Mollusca). In: HARTMANN C., BARCLAY M., WEIPER T. J. (eds), Biodiversität und Naturausstattung im Himalaya VI. Verein der Freunde \& Förderer des Naturkundemuseums Erfurt e.V., Erfurt, pp. 143-151.

Godwin-Austen H. H. 1876. On the Cyclostomacea of the Dafla Hills, Assam. Journal of the Asiatic Society of Bengal 45: 171-184.

GUDE G. K. 1921. Land operculates (Cyclophoridae, Truncatellidae, Assimineidae, Helicinidae). The Fauna of British India, including Ceylon and Burma, Mollusca III. Available online at https://www.biodiversitylibrary. org/item/46616\#page/5/mode/1up
HutTon T., BEnSON W. H. 1838. On the land and fresh-water shells of the western Himálaya. The Journal of the Asiatic Society of Bengal 7: 211-218. Available online at https://www.biodiversitylibrary. org/item/123650\#page/259/mode/1up

Kerney M. P., CAmeron R. A. D. 1979. A field guide to the land snails of Britain and North-west Europe. Collins, London.

PÁll-Gergely B., Hunyadi A., MAassen W. J. M. 2014. Review of Rhaphaulus L. Pfeiffer 1856 and Streptaulus Benson 1857 species with description of $R$. tonkinensis n. sp. from Vietnam (Gastropoda: Pupinidae). Journal of Conchology 41: 565-573.

PÁll-Gergely B., Fehér Z., HunYadi A., AsAmi T. 2015. Revision of the genus Pseudopomatias and its relatives (Gastropoda: Cyclophoroidea: Pupinidae). Zootaxa 3937 (1): 1-49. https://doi.org/10.11646/zootaxa.3937.1.1

SOWERBY G. B. [1] 1850. Descriptions of some additional species of the genus Cyclostoma. Figured in supplementary plates XXXI. A. and XXXI. B. In: SOWERBY G. B. [2] (ed.), Thesaurus conchyliorum, or monographs of shells 1. Available online at https://www.biodiversitylibrary.org/item/150311\#page/167/mode/1up

Received: June 25th, 2019

Revised: July 16th, 2019

Accepted: July 22nd, 2019

Published on-line: September 14th, 2019 